\title{
Mardin'de Çekilen Dizi ve Filmlere Dönük Yerel Halkın Algısı
}

Yrd. Doç. Dr. İsmail KERVANKIRAN

Süleyman Demirel Üniversitesi, Fen-Edebiyat Fakültesi, Coğrafya Bölümü, Isparta, e-posta: ismailkervankiran@sdu.edu.tr

Doç. Dr. Murat ÇUHADAR

Süleyman Demirel Üniversitesi, İktisadi ve İdari Bilimler Fakültesi, Turizm İşletmeciliği Bölümü, Isparta, e-posta: muratcuhadar@sdu.edu.tr

\section{Öz}

Zengin bir kültürel mirasa sahip olan Mardin, gerek sahip olduğu tarihi, kültürel ve doğal zenginlikleri, gerekse geçmiş yıllardan günümüze kadar ulaşan toplumsal değerlerinin özgünlüğünden dolayı yıllardır birçok film ve dizi yapımcısının tercih ettiği bir mekân olmuştur. Bu çalışmada, yerel halkın Mardin ilinde çekilen televizyon dizileri ve filmlerin ekonomik, kültürel, çevresel etkilerine ve Mardin turizmine katkısına yönelik algılarının belirlenmesi amaçlanmıştır. Çalışmada veri toplama aracı olarak anket tekniği seçilmiş ve kolayda örnekleme yaklaşımı ile Mardin ilinde yaşayan 401 birey ile yüz yüze görüşülerek veriler elde edilmiştir. Elde edilen veriler, frekans analizleri, Mann-Whitney U ve Kruskall-Wallis testleri ile analiz edilmiştir. Araştırma bulgularına göre yöre halkının, Mardin ilinde çekilen dizi ve filmlerin, şehrin ekonomisine ve tanıtımına olumlu katkı sağladığı, bununla beraber, kültürünün yanlış aktarılması, yaşam tarzlarının abartılması ve dizilerin ekonomik rant amacıyla çekilmeleri gibi olumsuz algılara sahip oldukları gözlenmiştir.

Anahtar Kelimeler: Mardin, Dizi ve Filmler, Yerel Halk.

Not: Bu çalışma, 18. Ulusal Turizm Kongresi'nde bildiri olarak sunulmuş, gelen görüş ve öneriler doğrultusunda genişletilerek yeniden kaleme alınmıştır.

\section{Önerilen Atıf:}

Kervankıran, İ. ve Çuhadar, M. (2018). Mardin'de Çekilen Dizi ve Filmlere Dönük Yerel Halkın Algısı Türk Turizm Araştırmaları Dergisi, Cilt.2, Sayı.1, ss. 44-59. 


\title{
The Perception of Local People towards Films and TV Series Filmed in Mardin
}

\section{Assistant Prof. Dr. İsmail KERVANKIRAN}

Süleyman Demirel University, Faculty of Arts and Sciences, Department of Geography, Isparta, email: ismailkerkankiran@sdu.edu.tr

\section{Associate Prof. Dr. Murat ÇUHADAR}

Süleyman Demirel University, Faculty of Economics and Administrative Sciences, Tourism Management Department, Isparta, e-mail: muratcuhadar@sdu.edu.tr

\begin{abstract}
Having a rich cultural heritage, Mardin has been a place of choice for many film and TV series producers for years, due to the historical, cultural and natural richness it has, and the authenticity of its social values, which have reached daily from past years. In this study, it was aimed to determine the perceptions of the local people about the economic, cultural and environmental effects of films and TV series filmed in Mardin and contribution to Mardin tourism. In the study, the questionnaire technique was chosen as the data collection tool and the data were obtained by face to face interview with 401 individuals living in Mardin province with convenience sampling approach. The obtained data were analyzed by frequency analysis, Mann-Whitney $U$ and Kruskal-Wallis tests. According to research findings, local people think that television series and films shot in the region contribute positively to the economy and promotion of the city. However, it has been observed that they have negative perceptions such as misunderstanding of cultures, exaggerated lifestyles, and the attempt to obtain economic rents.
\end{abstract}

Keywords: Mardin Province, TV Series and Films, Local People.

\section{Suggested Citation:}

Kervankıran, İ. ve Çuhadar, M. (2018). The Perception of Local People towards Films and TV Series Filmed in Mardin, Journal of Turkish Tourism Research, Vol.2, Issue.1, pp.44-59. 


\section{GíRiş}

Kültür turizminin bir alt türü olarak değerlendirilen film turizmi, eğlence sektörünün gelişmesi ve ülkeler arası seyahatin artması ile birlikte önemi gittikçe artan bir turizm türü haline gelmiştir (Hudson ve Ritchie, 2006: 256). Filmlerin destinasyon tanıtımında etkili bir araç olabileceklerini, filmlerin ya da TV dizilerinin yerel topluma ya da ülkeye sağlayacağı, imajı olumlu yönde etkileme ya da ev sahibi mekânın farkındalık seviyesini artırma gibi soyut faydaları da bulunmaktadır (Kim ve Richardson, 2003). Bu nedenle sinema, ürün yerleştirme yoluyla önemli bir pazarlama iletişim aracı haline gelmiştir. İçerisine destinasyon ürünü yerleştirilmiş filmler, destinasyon imajına olumlu katkı sağlamaktadırlar. Böylece destinasyon rakipler arasında farklılaşmakta ve uzun süreli bir ilgi yaratmaktadır (Saltık vd., 2010: 41-50). Bu ilgi destinasyon imajını etkilediği gibi televizyon dizilerindeki ve filmlerdeki karakterler vasıtasıyla hedef kitlenin giyim tarzlarını ve davranışlarını da etkilemektedir. Örneğin; Asmalı Konak dizisindeki Sümbül Hanım eşarpları, Muhteşem Yüzyıl dizisindeki Hürrem Sultan'ın yüzüğü ve saç rengi, Ezel dizisindeki "Dayı ve yeğen" konuşma kalıpları örneklerden bazılarıdır (Çakmak vd., 2011). Diziler, seyirciler ve mekânlar arasında kurulan bu bağ sonucunda dizilerin çekildiği bölgeye olan ziyaretler de artmaktadır. Nitekim "Yüzüklerin Efendisi" filmi Yeni Zelanda'ya, "Mumya" filmi Mısır'a, "Da Vinci Şifresi" filmi Paris'e, "Er Ryan'ı Kurtarmak" filmi Normandiya'ya, "Miami Vice" dizisi Miami'ye, "Dallas" dizisi Dallas'a, "Hayalet Sürücü 2" filmi Kapadokya'ya, "Skyfall" filmi ise İstanbul'a olan turizm talebini olumlu yönde etkilemiştir. Bu bölgelerdeki turist talebi verilerine bakıldığında, filmin ya da dizilerin gösterime girdiği yılın sonrasında ziyaretçi sayısında önemli artışın olduğu görülmektedir (Kervankıran ve Aktürk, 2016). Bu konuda Türkiye'de en önemli örneklerden birisi Asmalı Konak dizisidir. Peribacaları ile bölgenin mistik yerlerinin görüntüsü ve bölgeye ait geleneksel değerlerin dizi içerisinde yer alması (Çakmak vd., 2011) dizide sahnelenen mekanlara, geleneksel kültüre ve yaşam tarzına olan ilgiyi artırmıştır. Bu diziden sonra Kapadokya bölgesi özellikle yerli turistler açısından potansiyel turizm pazarı haline gelmiştir. Diğer örnek ise 2000 yılından sonra Türk dizilerinin Ortadoğu, Kuzey Afrika ve Balkanlar'daki pek çok ülkede milyonlarca izleyiciye ulaşması, bu bölgelerden Türkiye'ye olan turist akışını artırdı. Türkiye'nin tarihi, turistik ve doğal güzellikleri diziler aracılığı ile milyonlarca komşu ülke vatandaşına tanıtılarak, turistik olarak çekiciliği arttırıldı. Hem dizilerin çekildiği mekânları hem de dizilerdeki güzel İstanbul manzaralarını görmek isteyen turistler Türkiye'ye gelerek bu ülkeyi yakından tanıma fırsatı buldu (Nuroğlu, 2013). Nitekim Balli vd., (2013) yaptığı çalışmada, Orta Doğu ve Doğu Avrupa'da karşılıklı vize anlaşmalarının yapılması ile birlikte Türk dizilerinin popülerliğinin artışının bu ülkelerden gelen turist sayısını artırdığı sonucuna ulaşmıştır. Hatta dizilerin televizyonlarda gösterildiği saat sayısı ile bu ülkelerden gelen turist sayısı arasında pozitif bir korelasyonun olduğu görülmektedir (Balli vd., 2013). Gümüş, Ihlamurlar Altında, Deli Yürek, Kurtlar Vadisi, Binbir Gece, Ezel, Dudaktan Kalbe, Muhteşem Yüzyıl gibi diziler, önceleri tarihi, dini ve kültürel yakınlıktan dolayı Türkiye'ye yakın komşu ve yakın ülkelerde ilgi görürken daha sonraları farklı siyasi, dini ve kültürel özelliklere sahip ve Türkiye'den kilometrelerce uzaklıktaki ülkelerde de (Güney Amerika ülkeleri gibi) ilgi görmeye başlamıştır. Bu dizilerin gösterime girdiği ülkelerde Türkiye hakkındaki olumsuz imajın azaldığı gibi, Türk kültürüne ve yaşam tarzına yönelik merak oluşmuştur. Dizilerdeki karakterler rol model olarak görülmüş, sinema ve dizilerin çekildiği mekânlara olan ilgi artmış ve bunun sonucunda oluşan merak ve hayranlık Türkiye'ye olan yabancı turist talebini de olumlu etkilemiştir.

Son yıllarda popüler medya, etkileme ve bağımlılık oluşturma aracı olarak edebiyattan uyarladığ etmeyi veya denemeyi isteyebileceği belirgin aktiviteler sunmanın yanı sıra, filmin geçtiği yerlerle güçlü mekânsal bağlar kurma gücüne de sahiptir (Riley vd., 1998). Zaman içinde 
filmlerde öykünün geçtiği destinasyona yönelik ziyaretçi talebinin artması, filmlerin, destinasyonların tanıtım aracı olarak içerdiği potansiyeli ortaya çıkarmıştır. Filmlerin çekildiği mekanlar, stüdyolar, oteller, evler ve diğer mekanlar, filmin elde ettiği başarıya göre turistik açıdan büyük çekim merkezleri olabilmektedirler. Sonuç olarak destinasyonların bir ürün olarak filmlere yerleştirilmesi uygulaması, sağladığı avantajların farkına varılması ile giderek daha fazla kullanılmakta ve destinasyon pazarlamasında artarak tercih edilmektedir (Yllmaz ve Yolal, 2008). İzleyiciyi, bir ürün olarak destinasyona aşina hale getirmek suretiyle filmler, ekranda sahnelenen ya da ismi geçen destinasyonları ziyaret etme yönünde potansiyel pazarı teşvik etmektedirler (Saltık vd., 2010: 41-50). Filmlerin ve dizilerin mekânların farkındalığını artırdığını ve karar verme süreçlerinde etkili olduğunu anlayan pazarlama sorumluları, pazarlama ve tanıtım sorumluluğunu üstlendikleri destinasyonların, film ve dizi çekimlerine ev sahipliği yapmasını sağlamak için, gittikçe artan bir biçimde yapımcılarla beraber çalışmaktadırlar (Kim ve Richardson, 2003). Son yıllarda geleneksel pazarlama teknikleri yerine daha düşük bütçeyle yaratıcı, yenilikçi, akılcı ve dikkat çekici teknikler kullanılmaya başlanmıştır. Filmler ve filmin çekildiği mekanlar arasındaki ilişkinin orada yaşayan yerel halkla iletişime geçilerek kurulmasına karşın maalesef bu konunun çok fazla önemsenmediği görülmektedir (Piggott vd., 2004: 211). Bununla birlikte diziler veya filmler çekilen bölgeyi, ülkeyi veya toplumu yanlış, önyargılı ya da kötü olarak gösterdiği takdirde, o bölgeye olan turist akışını olumsuz yönde etkilemektedir. Dolayısı ile çekilen filmin veya dizinin içeriği, yaklaşım tarzı veya kurgusu, filmin çekildiği mekân ve bu mekânda yaşayan toplum üzerinde olumlu ya da olumsuz etkisi olabilmektedir (Kervankıran ve Aktürk, 2016).

Türkiye; coğrafi yapısı, uygun hava koşulları ve tarihi yerleriyle doğal bir çekim platosu olmasına karşın, yılda 10 ay film çekilebilen ancak bu doğal platodan yararlanamayan bir ülkedir. Sinemanın evrensel diliyle Türkiye'yi tanitmak en kolay ve etkili yoldur (Dorsay, 1998). Türk filmlerinin olumlu Türk imajı çizmesi 1990'ların sonlarına doğru Türk sinemasının atılıma geçmesiyle artar. Son zamanlarda gerek yurt dışında gerek yurt içindeki genç yönetmenlerin filmleri yabancı ülkelerde ses getirmeye başlamıştır. Uluslararası alanda başarı kazanmış Türk sinemalarının gösterildiği ülkelerde haklarında olumlu yazıların yazılması, olumlu Türk imajının oluşturulmasına ve dolayısıyla turizme olumlu katkı sağlamasına etkisi göz ardı edilmemelidir. Sonuçta "sanatsal" kimlik insanların bakış açılarını daha olumlu bir yöne kaydırmaktadır. Genelde olumsuz haberlerle gündeme gelen ülkemizin sanatsal faaliyetlerle medyada yer alması olumlu bir etki yaratacaktır (Yanmaz, 2011). Al Tamimi (2012)'de yer alan bir habere göre 2008 yılında Türkiye'ye gelen turist sayısı bir önceki yıla göre 70000 artış göstermiş, bu artışın nedeni öncelikli olarak doğal ve tarihi güzellikler değil, dizi etkisi olarak düşünülmüştür. Yine Ürdün'deki bir seyahat acentesi düzenledikleri tura Gümüş dizisinin çekildiği yalıyı ilave edince kayıtlarda yüzde 20-25 artış gözlemlemiştir. Diğer yandan Balkan Insight raporuna göre, 2011 yılında Makedonyalıların en çok rağbet ettiği tatil mekânı favori dizilerinin çekildiği yer olan İstanbul olmuş ve Balkanlardaki seyahat acenteleri de dizi setlerini turlarına ilave etmeye başlamışlardır (Nuroğlu, 2013).

İlgili literatür incelendiğinde, film ve dizilerin turizme olan etkilerine yönelik birçok çalışma olduğu görülmektedir (Tolüngüç, 1990; Tooke ve Baker, 1996; Riley vd., 1998; Busby ve Klug, 2001; Hudson ve Ritchie, 2006; Beeton, 2008; Yılmaz ve Yolal, 2008; Şahbaz ve Kılıçlar, 2009; Saltık vd., 2010; Yanmaz, 2011; Çakmak, vd., 2011; Balli vd., 2013; Çakır, 2014; Akdu ve Akın, 2016; Özdemir Güzel ve Aktaş, 2016; Atsız ve Kızılırmak, 2017). Film ve dizilerde gösterilen destinasyon sunumu, görsel ve sözlü veya işitsel olmak üzere genelde iki türlü yapılmaktadır. Bunlardan ilki filmin arka planında görülmektedir. Örneğin, sokak sahnesinde veya film seti içerisinde kameranın görüntü aldığı yerde arka planda görüntülenebilir. Diğeri ise işitsel veya sözlüdür (Russell; 1998: 358). Her iki şekilde yapılan sunum sonucunda filmler ve diziler 
destinasyonun imajını olumlu ya da olumsuz yönde değiştirebilmektedir. Dolayısıyla filmlerin ve dizilerin turistlerin satın alma karar süreçleri üzerinde etkili olduğunu söylemek mümkündür. $\mathrm{Bu}$ çerçevede Şahbaz ve Kılıçlar (2009), Mardin ilinde çekimleri gerçekleştirilen filmlerin ve dizilerin, Mardin'i ziyaret eden yerli turistlerin zihnindeki destinasyon imajını farklılaştırıp farklılaştırmadığını araştırmış ve sonuç olarak; çekimleri Mardin'de gerçekleştirilen dizileri ve filmleri ilgi çekici bulan yerli turistler Mardin'e ilişkin olumlu bir imaja sahip olduklarını belirtmişlerdir. Bununla birlikte filmler ve filmin çekildiği mekanlar arasındaki ilişkinin orada yaşayan yerel halkla iletişime geçilerek kurulmasına karşın maalesef bu konunun çok fazla önemsenmediği görülmektedir (Piggott vd., 2004:211). Bir bölgedeki turizmin sürdürülebilirliği için, turizm yönüyle gelişmiş olan ülkelerin modern yaklaşımları takip edilmeli, klasik sı ̆̆ anlayıştan daha kapsamlı, yöre halkının katılımını ve bütünleşik sistem yaklaşımını öngören politikaların izlenmesi gerekir (Tosun, 2001). Toprak (2015)'ın Mardin'de halkın turizmin ekonomik, sosyal ve çevresel etkilerini göz önüne alarak yaptığı çalışmasında; katılımcıların turizmin ekonomik etkilerini önemsediği, sosyal ve çevresel etkileri ise daha az önemsediği sonucuna varmıştır. Bu doğrultuda halkın duyarlılıkları göz önüne alınarak çevreyle uyumlu ve sürdürülebilir projeler geliştirilmesi ve özellikle kamunun bölgede turizme yönelik uyguladığ1 proje ve yatırımlar için yerel halkın desteğinin alması gerektiğini önermiştir (Toprak, 2015). Bu çalışma, film ve dizilerin çekildiği mekânlarda yaşayan yerel halkın, çekilen film ve dizilerin etkilerine, Mardin kimliğinin tanıtımına ve Mardin turizmine katkılarına yönelik algılarını analiz ederek, film ve dizilerin yereldeki yansımaları konularına odaklanmıştır.

\section{Mardin'in Genel Özellikleri ve Turizm Çekicilikleri}

Mardin; yeryüzünde tarımın doğduğu, neolitik ve kalkolitik kültürlerin geliştiği "bereketli hilal" içerisinde en önemli yörelerden biridir (Aydın vd., 2000). İl nüfusunun yaklaşık \%44'ü kırsal kesimde yasayan Mardin'de tarım ağırlıklı bir sosyo-ekonomik yapı görülmektedir (Aydın, 2008). Fırat ve Dicle nehirleri arasında bir dağın tepesinde kurulmuş olan Mardin, Yukarı Mezopotamya'nın en eski şehirlerinden birini oluşturur. Dolayısı ile Mardin ilinin geleneksel ekonomik yapısı tarım, ticaret ve son zamanlarda artış gösteren imalat sanayi ve küçük çaplı sanayi ve el sanatlarına dayalıdır. Mardin kaya mimarisi alanında gelişim göstermeyi başarmış bir şehirdir. Bu durumun nedeni, Mardin'in dağlık bir alanda yer almasından dolayıdır. Ayrıca, dağlık olmasıyla beraber düz alanları da mevcuttur. Bu durum, kültürel anlamda bir mozaiği bünyesine katmıştır. Böylece, hanlar, kervansaraylar, mescitler, hamamlar, türbeler, kiliseler, manastırlar ve taş evler gibi kültürel unsuru içinde barındıran yapılar, düz alanlarda yapılmıştır (Karasu, 2013: 88). Mardin'in Anadolu'daki diğer kentlerden en önemli farkı 21. yüzyılda da kentte hatırı sayılır sayıda Hıristiyan nüfusun varlığı (göçlere rağmen) ve Mardin' de manastır yaşamının sürüyor olmasıdır. Kuşkusuz Anadolu'nun birçok kentinde küçük Hıristiyan toplulukları bulunmaktadır. Bununla birlikte Süryaniler, Ermeniler, Yahudiler, Kürtler, Araplar, Türkler, Yezidiler ve Şemsiler gibi birçok etnik ve dini grup bir arada yaşamaktadır (Soydan ve Şarman, 2013). Geçmişten günümüze binlerce yıllık zaman sürecinde Mardin'in belleğine işlemiş olan; farklı kültürleri, dinleri, dilleri, halkları ve yaşam tarzlarını bir arada yaşatma ruhu ve geleneği birçok insanı bu mekânlara çekmektedir. Bundan dolayı yaşanan bazı olumsuzluklara rağmen Mardin, Türkiye'nin doğu bölgelerindeki en önemli turizm destinasyonlarından birini oluşturmaktadır.

Mardin'in önde gelen doğal turizm çekicilikleri; mağaraları (Gümüşova Mağarası, İplik Mağarası, Şakolin Mağarası, Fikiye Mağarası, Kefilmerdin Mağarası, Dirkup Mağarası, Derinsu Mağarası, Dağ Mağarası, Haramiye Mağarası, Hanika Mağarası, Salah Mağarası, Hamazembari Mağarası, Gümüşyuva Mağarası, Avrıhan Mağarası, Kefilmelep Mağarası, Kefissanur Mağarası, 
Hapisnas Mağarası, Tınat Mağarası, Unveyri Şifa Mağarası, Hop Mağarası, Hessin Meryem Mağarası, Sercahan Mağarası, Zivinganter Mağarası ve Kıllıt Mağaraları) ve akarsuları (Gümüş Çayı, Çă̆ Çağ Suyu, Savur Çayı, Buğur Çayı, Hınız Deresi, Gülzar Deresi, Sultan Şeyhmus Deresi, Gurs Suyu, Büyük Dere ve Cehennem Deresi) ile oldukça önemli zenginliklere sahiptir (Mardin İl Kültür ve Turizm Müdürlüğü, 2015; Mardin Valiliği İl Çevre ve Orman Müdürlügü̈, 2011). Mardin etnik ve dini gruplar açısından Türkiye'nin en fazla çeşitlilik gösteren illerinden biridir ve ilde farklı dinlere ait birçok dini yapı bulunmaktadır. Bunlar içerisinde; Deyrulzafaran manastırı (Mardin), Mor Gabriel manastırı, Meryem Ana manastırı, Mor Yakup manastırı, Mor Malke manastırı, Sultan Kasım (Kasımiye) medresesi, Zinciriye (Sultan İsa) medresesi ve Şehidiye medresesi, Süryani eserleri, Sultan Kasım (Kasımiye) medresesi, Zinciriye (Sultan İsa) medresesi ve Şehidiye medresesi en önemli olanlarıdır. Yenikale (Saçlı Ali), Aznavur, Zarzavan, Şirvan gibi kaleleri, Dara Harabeleri, geleneksel evler, geleneksel el sanatları ve yemekleri ilin en önemli kültürel turizm çekiciliklerini oluşturmaktadır (Günal, 2005).

Turizm gelişimi ile birlikte Mardin'de el sanatlarının ön plana çıktı̆̆ı, bakırcılar çarşısı, butik oteller, telkâri gümüşçüler, Mardin Müzesi, yerel restoranların bulunduğu Eski Mardin diye anılan mekânın giderek turistik bir çekim merkezi olduğu ve Hilton vb. zincir otel markalarının Mardin'de artmaya başladığını, dolayısı ile Mardin ilinde turizm sektörünün gelişme kaydedeceğini ve bu gelişmenin ötekine, otantik olana, farklı olana arayış üzerinden devam edeceğini göstermektedir. Bununla birlikte Mardin'in giderek turistik bir merkez olması, yapıların turizm işletmelerine çevrilmesi, yerel halkın da yaşamını bir sahneleme çevresinde sergilemeye başladığı görülmekte ve yemekler, yerel halka özgü etkinlikler ve kültürel miras bir meta olarak kullanılmaktadır. Memnuniyeti sağlamak ve ilgi çekmek adına turiste farklı, otantik, eski gelebilecek her şey abartılı ve metalaştırılarak sunulmaktadır (Kaygalak vd., 2013). Gündüz ve Erdem (2013)'in çalışmasında Mardin'de turizmin yeni geliştiği için yerel halkın turizmin olumsuz etkilerinin farkına varmadığını ancak turist sayısının artmasıyla hem turistler hem de yerel halk açısından negatif etkilerin de artacağı, dolayısı ile şimdiden önlemlerin alınması gerektiği belirtilmektedir. Ayrıca Mardin'e gelen turistlerin kalış sürelerinin kısa ve turist başına düşen harcama miktarının oldukça düşük olması (Egresi vd., 2012), turizmin yerel ekonomiye olan katma değerini düşürmekte, bu ise turizmin bu bölgede gelişmesi için çaba harcayan ve yatırım yapan tüm kesimlerin planlarını olumsuz etkilemektedir. Bölgedeki mevcut kültür varlıklarının yeterince araştırılamaması, güvenlik ve ulaşım problemleri nedeniyle Mardin'de turizm, geç ele alınmış bir sektör konumundadır. Ancak UNESCO Dünya Mirası Kentler aday listesinde yer alan Mardin'in asıl listeye dahil edilme çalışmalarının AB Projeleri destekleriyle 2015 yılında da sürecek olması, Türkiye Turizm Stratejisi Eylem Planında (2007-2013) ve 2023 Türkiye Turizm Stratejisinde Marka Kent olarak gösterilmesi, turizm sektörünün geleceğine yönelik beklenti ve umutları arttırmaktadır (Toprak, 2015). Bu yönüyle Mardin'in sahip olduğu zenginliklerin ve çekiciliklerin tanınırlı̆̆ının artmasında ve turizm sektörünün beklenilen hedefleri gerçekleştirmesinde Mardin'de çekilen dizi ve filmlerin önemli katkısı bulunmaktadır.

\section{Mardin'de Çekilen Film ve Diziler}

Zengin bir mirasa sahip olan Mardin, gerek tarihi ve kültürel yapıların çeşitliliği ve otantikliğinden dolayı gerekse geçmiş yıllardan günümüze kadar ulaşan toplumsal yapının özgünlüğünden dolayı yıllardır birçok film ve dizi yapımcılarının tercih ettikleri mekânlardan birisi olmuştur. Televizyonun hayatımıza girmesinden bu yana dizi ve filmlere ev sahipliği yapmış olan şehirlerden birisi Mardin'dir. Mardin şehri, herkesin gidip görebileceği, gerek geçmişi, tarihi yapısı, gerekse yaşantısıyla kendisine çekmiştir. Geçmişten günümüze Mardin ilinde çekilen TV dizileri ve filmlerin bir özeti Tablo 1.'de verilmiştir. 
Tablo 1: Mardin İlinde Çekilen Film ve TV Dizileri

\begin{tabular}{|c|c|c|c|}
\hline Dizinin Adı & Özelliği & Dizinin Adı & Özelliği \\
\hline $\begin{array}{l}\text { Mardin Münih } \\
\text { Hattı }\end{array}$ & $\begin{array}{l}1986 \text { yilında TRT'de } \\
\text { yayınlanan dizi }\end{array}$ & Aşk Bir Hayal & $\begin{array}{l}2009 \text { yılı yapımlı, Midyat'ta } \\
\text { başlayıp İstanbul'da biten bir } \\
\text { dizi. }\end{array}$ \\
\hline Deli Yürek & $\begin{array}{l}\text { 1998-2002 yılları arasında } \\
\text { çekilen } 113 \text { bölümlük bir } \\
\text { dizi }\end{array}$ & Beşik Kertmesi & $\begin{array}{l}2002 \text { yılı yapımlı bir komedi } \\
\text { dizisi }\end{array}$ \\
\hline Berivan & $\begin{array}{l}\text { Çekimleri } 2002 \text { yılında } \\
\text { Mardin'de başlayıp, } \\
\text { sonrasında batıda devam } \\
\text { eden dizi }\end{array}$ & Firar & $\begin{array}{l}\text { 2011-2012 yapımlı Mardin'de } \\
\text { başlayıp İstanbul'da biten bir } \\
\text { dizi }\end{array}$ \\
\hline Aşka Sürgün & $\begin{array}{l}\text { 2005-2006 yılları arasında } \\
\text { çekilen dizi }\end{array}$ & Kadim Dostum & 2014 yılı yapımlı bir dizi \\
\hline Hiçbir Yerde & $\begin{array}{l}\text { Mardin-İstanbul arasında } \\
\text { geçen bir film }\end{array}$ & Aşktan Kaçılmaz & $\begin{array}{l}2016 \text { yapımlı } 11 \text { bölümlük bir } \\
\text { dizi }\end{array}$ \\
\hline Kara Duvak & $\begin{array}{l}\text { Tamamı Mardin'de çekilen } \\
2007 \text { yapımlı bir dizi }\end{array}$ & The Cut (Kesik) & 2014 yapımı bir film \\
\hline Mem u Zin & $\begin{array}{l}\text { Mardin / Nusaybin'de } \\
\text { çekilen bir film }\end{array}$ & Gönül Yarası & 2005 yapımlı bir film \\
\hline Büyü & 2004 yapımı bir korku filmi & Hükümet Kadını & $\begin{array}{l}2013 \text { 'de Midyat'ta çekilen } \\
\text { film. }\end{array}$ \\
\hline Sila & $\begin{array}{l}2006-2008 \text { yıllarında } \\
\text { Mardin ve İstanbul'da } \\
\text { çekilen dizi }\end{array}$ & Jan (S1z1) & $\begin{array}{l}\text { 2015-2016 arasında } \\
\text { yayınlanan dizi }\end{array}$ \\
\hline İncir Çekirdeği & $\begin{array}{l}2009^{\prime} \text { da Mardin'de çekilen } \\
\text { bir dizi }\end{array}$ & $\begin{array}{l}\text { Adını Kalbime } \\
\text { Yazdım }\end{array}$ & $\begin{array}{l}\text { 2013-2014 yılları arasında } \\
\text { çekilen dizi }\end{array}$ \\
\hline $\begin{array}{l}\text { Benim ve Roz'un } \\
\text { Sonbaharı }\end{array}$ & $\begin{array}{l}2009 \text { yapımlı Mardin, } \\
\text { Batman ve Hasankeyf'te } \\
\text { çekilen bir film }\end{array}$ & $\begin{array}{l}\text { İmam Ahmet Bin } \\
\text { Hanbel }\end{array}$ & $\begin{array}{l}2016 \text { yapımlı, Mardin ve } \\
\text { İstanbul'da çekilen bir dizi }\end{array}$ \\
\hline Ay Lav Yu & $\begin{array}{l}2010 \text { yılı yapımlı } \\
\text { Hasankeyf'e bağlı Tinne } \\
\text { Köyü'nde çekilen bir film }\end{array}$ & Göç Zamanı & 2016 yapımlı bir dizi \\
\hline Bir Bulut Olsam & $\begin{array}{l}2009 \text { yılında Süryani } \\
\text { konağında çekilen bir dizi }\end{array}$ & & \\
\hline
\end{tabular}

Mardin ili sınırları içerisinde çekilen dizilerden birisi olan 1986 yılı yapımlı "Mardin Münih Hattı" adlı dizi, o dönemde izleyicilerden büyük ilgi görmüştür. Günümüzde ise, en fazla üzerinde durulan Mardin dizi ve filmlerinin kan davası, terör, sosyal yaşantı, gelenekler vb. konularda olduğu dikkat çekmektedir. Mardin'de çekilen film ve dizilerin birkaç tanesi hariç çoğunluğunun işlediği konu ve dizi-filmlerin çekildiği mekânlar benzerdir. Ayrıca bu dizilerin çoğunun Mardin'de başlayıp daha sonra başka bir şehirde devam etmesi, Mardin imajının, kimliğinin ve kültürünün metalaşmasında önemli bir etken olduğu da düşünülmektedir.

\section{YÖNTEM}

Araştırma kapsamında, yerel halkın Mardin ilinde çekilen televizyon dizileri ve filmlere yönelik algılarını belirlemek amacıyla anket uygulaması gerçekleştirilmiştir. Çalışmada kullanılan anket 
formu iki bölümden oluşmaktadır. Anket formunun ilk bölümünde araştırmaya katılan bireylerin cinsiyet, yaş aralığı, meslek, gelir, eğitim ve medeni durumlarına ilişkin demografik bilgiler yer almaktadır. Anket formunun ikinci bölümünde ise, yerel halkın Mardin ilinde çekilen televizyon dizileri ve filmlere yönelik algılarının belirlenmesine yönelik ifadeler yer almaktadır. Anket formunun ikinci bölümünde yer alan ifadeler; "1: Kesinlikle Katılmiyorum, 2: Katılmıyorum, 3: Kısmen Katılıyorum, 4: Katılıyorum, 5: Kesinlikle Katılıyorum" sıra düzeni ile beşli Likert düzeninde hazırlanmıştır. Araştırmanın evrenini, Mardin ili merkezinde yaşayan 1860 yaş aralığındaki bireyler oluşturmaktadır. Türkiye İstatistik Kurumu'nun 2016 yılı adrese dayalı nüfus kayıt sistemi verilerine göre, Mardin ili merkez nüfusu 163725 kişidir. Nüfusun 83185'ini erkek, 80540'ını ise kadınlar oluşturmaktadır (TÜIK, 2016). Çalışmada, evreni oluşturan birey sayısının fazla olması, maliyet ve zaman gibi kısıtlllıklar nedeniyle örneklemeye gidilmiştir. Örneklem hacmi, \% 95 güven aralığında, \pm \% 5 yanılma payı ile 383 kişi olarak belirlenmiştir. Anket uygulaması, kolayda örnekleme yaklaşımı ile 2016 yılı Haziran ve Temmuz aylarında Mardin ili merkezindeki 401 bireye yönelik gerçekleştirilmiştir. Elde edilen veriler, frekans analizleri, Mann-Whitney U ve Kruskall-Wallis testleri ile analiz edilmiştir.

\section{BULGULAR}

Araştırma kapsamında, ankete katılan bireylerin demografik özelliklerine ilişkin bilgiler Tablo 2 'de verilmiştir.

Tablo 2' de araştırmaya katılan bireylerin cinsiyetlerine göre dağılımı incelendiğinde, \% 67,6'sının erkek ( $n=271), \% 32,4^{\prime}$ ünün $(n=130)$ ise bayanlardan oluştuğu görülmektedir. Araştırmaya katılan bireylerin yaş dağılımları incelendiğinde, katılımcıların \% 27,7'sinin "18-20", \% 38,3'ünün "2130 ", \% 19,5'inin “31-40", \% 10,5'inin "41-50" ve \% 4'ünün 50 ve üzeri yaş aralığında olduğu görülmektedir. Eğitim durumuna bakıldığında, lise (\% 40,4) ve ilköğretim $(\% 38,4)$ mezunlarının ilk sırada yer aldığı; bunu sırasıyla lisans (\% 12), lisansüstü (\% 4), ön lisans mezunları (\%3,5) ve okula gitmeyenlerin $(\%$ 1,7) takip ettiği görülmektedir. Katılımcıların \% 43,9'u evli, \% 52,6'sı bekâr ve \% 3,5'i ise dul ya da boşanmış olduklarını belirtmişlerdir. Ankete katılan bireylerin meslek dağılımları incelendiğinde, serbest meslek (\% 12,9), işçi (\% 15,5) ve ev hanımlarının (\% 14) birbirlerine yakın oransal dağılıma sahip oldukları görülmektedir. Öğrenci olduğunu beyan edenlerin oranı \% 26,2 ile ilk sirada yer almaktadır. Katılımciların \% 5,2'si devlet memuru; \% 5'i tüccar, \% 2, 2'si emekli, \% 0,5'i çiftçi ve \% 18,5'i diğer meslek dallarına mensup olduklarını beyan etmişlerdir. Katılımcıların gelir durumlarına bakıldığında, \% 20,2'sinin 1000 TL altında, \% 20,4'ünün 1001-2000 TL, \% 9,7'sinin 2001-3000 TL, \% 5,2'inin 3000 TL üzeri aylık gelire sahip oldukları ve \% 44,4'ünün ise düzenli bir gelire sahip olmadıkları görülmektedir. Yerel halkın, Mardin ilinde çekilen televizyon dizileri ve filmlere yönelik algılarını belirlemeye yönelik olarak anket formunda yer alan ifadelere katılma düzeyleri Tablo 3'de verilmiştir. 
Tablo 2. Katılımcıların Demografik Özellikleri

\begin{tabular}{|c|c|c|c|}
\hline & Değişken & $\mathbf{n}$ & $\%$ \\
\hline \multirow{3}{*}{ Cinsiyet } & Erkek & 271 & 67,6 \\
\hline & Kadın & 130 & 32,4 \\
\hline & Toplam & 401 & 100,0 \\
\hline \multirow{6}{*}{ Yaş Grubu } & $18-20$ & 111 & 27,7 \\
\hline & $21-30$ & 154 & 38,3 \\
\hline & $31-40$ & 78 & 19,5 \\
\hline & $41-50$ & 42 & 10,5 \\
\hline & 50 üzeri & 16 & 4,0 \\
\hline & Toplam & 401 & 100,0 \\
\hline \multirow{7}{*}{ Eğitim Durumu } & İlköğretim & 154 & 38,4 \\
\hline & Lise & 162 & 40,4 \\
\hline & Ön Lisans & 14 & 3,5 \\
\hline & Lisans & 48 & 12 \\
\hline & Yüksek Lisans-doktora & 16 & 4 \\
\hline & Okula Gitmemiş & 7 & 1,7 \\
\hline & Toplam & 401 & 100,0 \\
\hline \multirow{4}{*}{ Medeni Durum } & Evli & 176 & 43,9 \\
\hline & Bekâr & 211 & 52,6 \\
\hline & Diğer & 14 & 3,5 \\
\hline & Toplam & 464 & 100,0 \\
\hline \multirow{10}{*}{ Meslek } & Çiftçi & 2 & 0,5 \\
\hline & Tüccar & 20 & 5 \\
\hline & Serbest Meslek & 52 & 12,9 \\
\hline & İşçi & 62 & 15,5 \\
\hline & Devlet Memuru & 21 & 5,2 \\
\hline & Emekli & 9 & 2,2 \\
\hline & Öğrenci & 105 & 26,2 \\
\hline & Ev Hanımı & 56 & 14,0 \\
\hline & Diğer & 74 & 18,5 \\
\hline & Toplam & 401 & 100 \\
\hline \multirow{6}{*}{ Gelir Durumu } & 1000 TL altında & 81 & 20,2 \\
\hline & $1001-2000$ aras1 & 82 & 20,4 \\
\hline & 2001-3000 aras1 & 39 & 9,7 \\
\hline & 3000 TL üzeri & 21 & 5,2 \\
\hline & Düzenli Geliri Yok & 178 & 44,4 \\
\hline & Toplam & 401 & 100 \\
\hline
\end{tabular}

Katılımciların anket formunda yer alan ifadelere katılım düzeylerinin yorumlanması ve derecelendirilmesi, “Kesinlikle katılmıyorum (1.00-1.79)- Kesinlikle katılıyorum (4.20-5.00) puan sınırları kriterine göre değerlendirilmiştir. Aralıkların eşit olduğu varsayılmıs, aritmetik ortalamalar için puan aralığ1 0,79 olarak hesaplanmıştır (Kaplanoğlu, 2014: 273). Kullanılan puan sinır değerleri, ankete katılan bireylerin anket formunda yer alan ifadelere katılma durumlarına ait cevapların aritmetik ortalamasının eşit dört aralığını ifade etmektedir. Tablo 3 incelendiğinde, bireylerin anket formunda yer alan "Dizi oyuncuları ve yapımcıları, yerel halkla daha fazla iletişim kurmalıdır" ve "Dizilerin çekildiği mekânların korunmasına yönelik hassasiyet gösterilmelidir" ifadelerine çok yüksek düzeyde katılım gösterdikleri görülmektedir. Bununla birlikte, "Mardin' de çekilen dizilerin, Mardin'e ekonomik katkısı olmaktadır" "Mardin'de çekilen diziler, Mardin turizmine olumlu katkı sağlamaktadır" ifadelerine yüksek, "Mardin'de çekilen diziler, Mardin'in tarihi yapılarına zarar vermektedir" ifadesine ise düşük katılım gösterdikleri görülmektedir. Çalışmadan elde edilen çarpıcı bulgular arasında bölge halkının, film-dizi oyuncuları ve yapımcılarından yerel halkla daha fazla iletişim kurmalarına ve bölgede çekilen 
dizi ve filmlerde yerel halktan insanların da yer almalarına ilişkin ifadelere yüksek katılım göstermiş olmaları sayılabilir.

Tablo 3. Bireylerin Mardin' de Çekilen Dizi ve Filmlere İlişkin İfadelere Katılma

Durumları $(n=401)$

\begin{tabular}{|c|c|c|c|c|}
\hline & İfadeler & $\bar{X}$ & S.S. & Katılma Derecesi \\
\hline 1 & $\begin{array}{l}\text { Mardin'de çekilen diziler gerçek Mardin kültürünü } \\
\text { vansıtmıvor. }\end{array}$ & 3,66 & 1,399 & Yüksek \\
\hline 2 & $\begin{array}{l}\text { Mardin'de çekilen diziler, Mardin'in tanıtımına katkı } \\
\text { sağlamaktadır. }\end{array}$ & 3,51 & 1,204 & Yüksek \\
\hline 3 & $\begin{array}{l}\text { Mardin'de çekilen dizilerin, Mardin'e ekonomik katkısı } \\
\text { olmaktadır. }\end{array}$ & 3,46 & 1,131 & Yüksek \\
\hline 4 & $\begin{array}{l}\text { Mardin'de çekilen diziler Mardin halkının kültürünü } \\
\text { olumsuz etkilivor. }\end{array}$ & 3,38 & 1,425 & Orta \\
\hline 5 & $\begin{array}{l}\text { Mardin'de çekilen diziler, Mardin'in tarihi yapılarına } \\
\text { zarar vermektedir. }\end{array}$ & 2,41 & 1,341 & Düşük \\
\hline 6 & Dizilerde anlatılan yaşam tarzı abartılmaktadır. & 4,01 & 1,242 & Yüksek \\
\hline 7 & $\begin{array}{l}\text { Mardin'de çekilen diziler, Mardin turizmine olumlu } \\
\text { katkı sağlamaktadır. }\end{array}$ & 3,49 & 1,202 & Yüksek \\
\hline 8 & $\begin{array}{l}\text { Mardin'de çekilen dizilerin amacı ekonomik rant elde } \\
\text { etmektir. }\end{array}$ & 3,60 & 1,245 & Yüksek \\
\hline 9 & Mardin'de dizi ve sinema çekimine izin verilmemelidir. & 2,69 & 1,018 & Orta \\
\hline 10 & $\begin{array}{l}\text { Dizi oyuncuları ve yapımcıları, yerel halkla daha fazla } \\
\text { iletișim kurmalıdır. }\end{array}$ & 4,28 & 1,045 & Çok Yüksek \\
\hline 11 & $\begin{array}{l}\text { Dizilerin çekildiği mekânların korunmasına yönelik } \\
\text { hassasivet gösterilmelidir. }\end{array}$ & 4,43 & 1,018 & Çok Yüksek \\
\hline 12 & $\begin{array}{l}\text { Mardin'de çekilen film ve dizilerde yerel halktan insanlar } \\
\text { da yer almalıdır. }\end{array}$ & 4,05 & 1,224 & Yüksek \\
\hline
\end{tabular}

Çalışmada, çeşitli değişkenlere göre farklılıkları incelemek amacıyla gerçekleştirilecek istatistiksel testlerin seçimini (parametrik-nonparametrik) belirlemek amacıyla, kullanılan verilerin normal dağılıma uygunluğu sınanmış ve Kolmogorov-Smirnov testi uygulanmıştır. Test sonucunda, çalışmada kullanılan verilere ait hesaplanan istatistiksel anlamlılık değerlerinin tümünün 0,05 ' den küçük olduğu $(\mathrm{p}<0,05)$ görülmüş, dolayısıyla verilerin normal dağılıma uygun bir ana kitleden gelmediği tespit edilmiştir. Bununla birlikte, çalışmada kullanılan verilerin ölçüm seviyesinin nominal ve ordinal düzeyde olması nedeniyle, parametrik olmayan testlerin kullanılmasının uygun olacağına karar verilmiştir. Anket uygulamasına katılan bireylerin cinsiyetleri ile Mardin ilinde çekilen televizyon dizileri ve filmlere yönelik algılarını belirlemeye yönelik ifadelere verdikleri cevapların dağılımları arasında istatistiksel olarak anlamlı farklılığın olup olmadığını araştırmak amacıyla Mann-Whitney U testi uygulanmış, sonuçları Tablo 4'te verilmiştir. Test sonuçları incelendiğinde, bireylerin anket formunda yer alan 12 ifadenin 10'una katılım düzeyleri ile cinsiyet dağılımları arasında istatistiksel anlamlı bir farklılık bulunmadığı görülmüştür. Anlamlı farklılık, "Mardin'de çekilen film ve diziler, Mardin turizmine olumlu katkı sağlamaktadır ( $\mathrm{p}=0.025<0.05)$ " ve "Mardin'de çekilen film ve dizilerin amacı ekonomik rant elde etmektir $(\mathrm{p}=0.001<0.05)$ " ifadelerinde görülmüştür. Diğer bir ifadeyle bireylerin bu ifadelere katılım düzeyleri, cinsiyete göre farklılık göstermektedir. 
Tablo 4. Cinsiyete Göre Mann-Whitney U Testi

\begin{tabular}{|c|c|c|c|c|c|}
\hline & Cinsiyet & $\mathbf{n}$ & $\begin{array}{c}\text { Sira } \\
\text { Ortalaması }\end{array}$ & $\begin{array}{c}\text { Sira } \\
\text { Toplamları }\end{array}$ & Anlamlılık \\
\hline \multirow{2}{*}{$\begin{array}{l}\text { Mardin'de çekilen film ve diziler, } \\
\text { Mardin turizmine olumlu katkı } \\
\text { sağlamaktadır. }\end{array}$} & Erkek & 271 & 209.63 & 56809.00 & \multirow{2}{*}{$\begin{array}{c}0,025 \\
P<0.05\end{array}$} \\
\hline & Kadın & 130 & 183.02 & 23792.00 & \\
\hline \multirow{2}{*}{$\begin{array}{l}\text { Mardin'de çekilen film ve dizilerin } \\
\text { amacı ekonomik rant elde } \\
\text { etmektir. }\end{array}$} & Erkek & 271 & 213,62 & 57892,00 & \multirow{2}{*}{$\begin{array}{c}0,001 \\
\mathrm{P}<0.05\end{array}$} \\
\hline & Kadın & 130 & 174,68 & 22709,00 & \\
\hline
\end{tabular}

Anket sorularını cevaplayan bireylerin yaş grupları ile Mardin ilinde çekilen televizyon dizileri ve filmlere yönelik algılarını belirlemeye yönelik ifadelere verdikleri cevaplar arasında istatistiksel olarak anlamlı farklılığın olup olmadığını araştırmak amacıyla Kruskal-Wallis testi uygulanmış, sonuçları Tablo 5'te sunulmuştur. Test sonuçları incelendiğinde, bireylerin anket formunda yer alan 12 ifadenin 9'una katılım düzeyleri ile yaş dağılımları arasında istatistiksel olarak anlamlı bir farklılık bulunmadığı görülmüştür. Anlamlı farklılığın görüldüğü ifadeler "Mardin'de çekilen film ve diziler gerçek Mardin kültürünü yansıtmıyor ( $p=0.008<0.05$ )", "Film ve dizilerde anlatılan yaşam tarzı abartılmaktadır $(\mathrm{p}=0.014<0.05)$ ", "Mardin'de çekilen film ve dizilerin amacı ekonomik rant elde etmektir $(p=0.024<0.05)$ " şeklindedir. Diğer bir ifadeyle bireylerin bu ifadelere katılım düzeyleri, yaş gruplarına göre farklılık göstermektedir.

Kruskall-Wallis testi ile tespit edilen, bireylerin yaş grupları ile anket formunda yer alan ifadelere katılım dağılımları arasındaki istatistiksel olarak anlamlı farklılıkların, hangi gruplar arasında ortaya çıktığını belirlemek amacıyla Mann-Whittney U testleri uygulanmıştır. Uygulanan MannWhitney U testleri sonucunda istatistiksel olarak anlamlı farklılıkların tespit edildiği yaş grupları, Tablo 5'te yer alan "Gruplar Arası Anlamlı Fark" sütununda verilmiştir.

Ankete katılan bireylerin eğitim durumları ile Mardin ilinde çekilen televizyon dizileri ve filmlere yönelik algılarını belirlemeye yönelik ifadelere verdikleri cevaplar arasında istatistiksel olarak anlamlı bir farklılık olup olmadığını araştırmak amacıyla Kruskal-Wallis testi uygulanmış, sonuçları Tablo 6'da verilmiştir. Uygulanan test sonucunda bireylerin, anket formunda yer alan 12 ifadenin 8'ine katılım düzeyleri ile eğitim durumları arasında istatistiksel olarak anlamlı bir fark olmadığı görülmüştür. 
Tablo 5. Yaş Gruplarına Göre Kruskall-Wallis Testi

\begin{tabular}{|c|c|c|c|c|c|}
\hline & $\begin{array}{l}\text { Yaş } \\
\text { Aralığ }\end{array}$ & $\mathbf{n}$ & $\begin{array}{c}\text { Sira } \\
\text { Ortalaması }\end{array}$ & $\begin{array}{l}\text { Gruplar Arası } \\
\text { Anlamlı Fark }\end{array}$ & Anlamlılık \\
\hline \multirow{5}{*}{$\begin{array}{l}\text { Mardin'de çekilen film ve diziler gerçek } \\
\text { Mardin kültürünü yansıtmıyor. }\end{array}$} & $\begin{array}{l}\text { 20'den } \\
\text { küçük }\end{array}$ & 111 & 177,11 & \multirow{5}{*}{$1-4$} & \multirow{5}{*}{$\begin{array}{l}0.008 \\
P<0.05\end{array}$} \\
\hline & $20-30$ yaş & 154 & 195,02 & & \\
\hline & $31-40$ yaş & 78 & 220,54 & & \\
\hline & $41-50$ yaş & 42 & 237,06 & & \\
\hline & $\begin{array}{c}50 \text { yaş ve } \\
\text { üzeri }\end{array}$ & 16 & 234,34 & & \\
\hline \multirow{5}{*}{$\begin{array}{l}\text { Film ve dizilerde anlatılan yaşam tarzı } \\
\text { abartılmaktadır. }\end{array}$} & $\begin{array}{l}20 \text { 'den } \\
\text { küçük }\end{array}$ & 111 & 182,92 & \multirow{5}{*}{$1-3$} & \multirow{5}{*}{$\begin{array}{c}0.022 \\
\mathrm{P}<0.05\end{array}$} \\
\hline & $20-30$ yaş & 154 & 192,80 & & \\
\hline & $31-40$ yaş & 78 & 233,60 & & \\
\hline & 41-50 yaş & 42 & 206,38 & & \\
\hline & $\begin{array}{c}50 \text { yaş ve } \\
\text { üzeri }\end{array}$ & 16 & 232,31 & & \\
\hline \multirow{5}{*}{$\begin{array}{l}\text { Mardin'de çekilen film ve dizilerin } \\
\text { amacı ekonomik rant elde etmektir. }\end{array}$} & $\begin{array}{l}20 \text { 'den } \\
\text { küçük }\end{array}$ & 111 & 171,01 & \multirow{5}{*}{$1-2$} & \multirow{5}{*}{$\begin{array}{c}0.019 \\
P<0.05\end{array}$} \\
\hline & 20-30 yaş & 154 & 215,17 & & \\
\hline & $31-40$ yaş & 78 & 211,11 & & \\
\hline & $41-50$ yaş & 42 & 208,96 & & \\
\hline & $\begin{array}{c}50 \text { yaş ve } \\
\text { üzeri }\end{array}$ & 16 & 202,44 & & \\
\hline
\end{tabular}

(Gruplar Arası Anlamlı Fark Sütununda 1=20' den küçük, 2= 20-30, 3= 31-40, 4= 41-50, 5= 50 yaş ve üzeri grupları temsil etmektedir)

Analizlerde anlamlı farklılığın tespit edildiği ifadelerin "Mardin'de çekilen diziler, Mardin'in tanıtımına katkı sağlamaktadır ( $\mathrm{p}=0.009<0.05)$ ", "Mardin'de çekilen diziler, Mardin turizmine olumlu katkı sağlamaktadır ( $\mathrm{p}=0.043<0.05)$ ", "Mardin'de çekilen dizilerin amacı ekonomik rant elde etmektir $(\mathrm{p}=0.012<0.05)$ " ve "Dizilerde yerel halktan insanlar da oyuncu olarak rol almalıdır $(p=0.001<0.05)^{\prime \prime}$ olduğu tespit edilmiştir. Kruskall-Wallis testi ile tespit edilen, bireylerin eğitim durumları ile anket formunda yer alan ifadelere katılım dağılımları arasındaki istatistiksel olarak anlamlı farklılıkların, hangi gruplar arasında ortaya çıtığını belirlemek amacıyla MannWhittney U testleri uygulanmıştır. Uygulanan Mann-Whitney U testleri sonucunda istatistiksel olarak anlamlı farklılıkların tespit edildiği eğitim grupları, Tablo 6'da yer alan "Gruplar Arası Anlamlı Fark" sütununda verilmiştir. 
Tablo 6. Eğitim Durumuna Göre Kruskall-Wallis Testi

\begin{tabular}{|c|c|c|c|c|c|}
\hline & Eğitim Durumu & $\mathbf{n}$ & Sira Ortalaması & $\begin{array}{l}\text { Gruplar Arası } \\
\text { Anlamlı Fark } \\
\end{array}$ & Anlamlılık \\
\hline \multirow{6}{*}{$\begin{array}{l}\text { Mardin'de çekilen film ve } \\
\text { diziler Mardin'in } \\
\text { tanıtımına katkı } \\
\text { sağlamaktadır. }\end{array}$} & İlköğretim & 154 & 216,66 & \multirow{6}{*}{$5-6$} & \multirow{6}{*}{$\begin{array}{c}0.009 \\
p<0.05\end{array}$} \\
\hline & Lise & 162 & 189,03 & & \\
\hline & Ön lisans & 14 & 214,71 & & \\
\hline & Lisans & 48 & 192,32 & & \\
\hline & Lisansüstü & 16 & 145,03 & & \\
\hline & Eğitimi Yok & 7 & 293,43 & & \\
\hline \multirow{6}{*}{$\begin{array}{c}\text { Mardin'de çekilen film ve } \\
\text { diziler Mardin turizmine } \\
\text { olumlu katkı } \\
\text { sağlamaktadır. }\end{array}$} & İlköğretim & 154 & 205,95 & \multirow{6}{*}{$\begin{array}{l}5-6 \\
4-6 \\
1-4\end{array}$} & \multirow{6}{*}{$\begin{array}{c}0.043 \\
p<0.05\end{array}$} \\
\hline & Lise & 162 & 209,59 & & \\
\hline & Ön lisans & 14 & 213,64 & & \\
\hline & Lisans & 48 & 172,63 & & \\
\hline & Lisansüstü & 16 & 129,56 & & \\
\hline & Eğitimi Yok & 7 & 226,00 & & \\
\hline \multirow{6}{*}{$\begin{array}{l}\text { Mardin'de çekilen film ve } \\
\text { dizilerin amacı ekonomik } \\
\text { rant elde etmektir. }\end{array}$} & İlköğretim & 154 & 227,36 & \multirow{6}{*}{$1-2$} & \multirow{6}{*}{$\begin{array}{c}0.012 \\
p<0.05\end{array}$} \\
\hline & Lise & 162 & 181,59 & & \\
\hline & Ön lisans & 14 & 198,86 & & \\
\hline & Lisans & 48 & 182,65 & & \\
\hline & Lisansüstü & 16 & 197,88 & & \\
\hline & Eğitimi Yok & 7 & 207,57 & & \\
\hline \multirow{6}{*}{$\begin{array}{l}\text { Çekilen film ve dizilerde } \\
\text { yerel halktan insanlar da } \\
\text { oyuncu olarak rol } \\
\text { almalıdır. }\end{array}$} & İlköğretim & 154 & 186,32 & \multirow{6}{*}{$3-6$} & \multirow{6}{*}{$\begin{array}{c}0.001 \\
p<0.05\end{array}$} \\
\hline & Lise & 162 & 214,83 & & \\
\hline & Ön lisans & 14 & 264,54 & & \\
\hline & Lisans & 48 & 213,16 & & \\
\hline & Lisansüstü & 16 & 152,88 & & \\
\hline & Eğitimi Yok & 7 & 103,29 & & \\
\hline
\end{tabular}

(Gruplar Arası Anlamlı Fark Sütununda 1= İlköğretim, 2= Lise, 3= Ön Lisans, 4= Lisans, 5= Lisansüstü, 6= Eğitimi yok eğitim düzeyine sahip grupları temsil etmektedir)

\section{SONUÇ ve ÖNERİLER}

Kültür turizmi altında ele alınan film turizmi, hem eğlence sektörünün büyümesi hem de seyahate çıkan kişi sayısının artması ile birlikte dünya genelinde gelişen bir turizm türü haline gelmiştir. Konuyla ilgili yazın incelendiğinde Türkiye'de, film-etkili turizm, televizyon dizileriturizm ilişkisi, film ve dizilerin destinasyon pazarlaması ve tanıtımı üzerine etkilerini (Yılmaz ve Yolal, 2008; Şahbaz ve Kılıçlar, 2009; Yanmaz, 2011; Çakmak vd., 2011; Çakır, 2014; Özdemir ve Aktaş, 2016) kaleme alan muhtelif çalışmalar olmakla birlikte, yerel halkın, yaşadığı bölgede çekilen dizi ve filmlere ilişkin algılarını analiz etmeye yönelik çalışmaların (Tatoğlu vd., 2002; Saltık vd., 2010) sınırlı olduğu görülmektedir. Yapılan çalışmaların büyük çoğunluğunun, Hudson ve Ritchie (2006) tarafından geliştirilen film-etkili turizm kavramından hareketle, dizi ya da filmlerin çekildiği bölgeye gelen turistlere yönelik olarak gerçekleştirildiği dikkat çekmektedir. Bu çalışma ise, film ve dizilerin çekildiği mekânlarda yaşayan yerel halkın, çekilen film ve dizilerin ekonomik, kültürel, çevresel etkilerine ve Mardin kimliğinin tanıtımına ilişkin algılarını analiz ederek, film ve dizilerin yereldeki yansımaları konusuna odaklanmıştır.

Çalışmadan elde edilen bulgular kısaca özetlenecek olursa, Mardin'de yaşayan yerel halkın, bölgede çekilen dizi ve filmlerin bölge ekonomisine, Mardin ilinin tanıtımına ve bölgede turizmin 
gelişimine olumlu katkıları olduğuna ilişkin ifadelere yüksek katılım gösterdiği görülmüştür. Bununla beraber, bölgede çekilen dizi ve filmlerin Mardin kültürünü yansıtmadığı, dizi ve filmlerde hayat tarzının abartılı olarak sunulduğu ve ekonomik rant amacıyla çekildiğine ilişkin olumsuz ifadelere de yüksek katılım gösterdikleri dikkat çekmektedir. Bu çalışmadan elde edilen bulguların, Tatoğlu ve diğerleri (2002) tarafından Kuşadası'nda yerel halka yönelik olarak yapılan çalışma sonuçları ile benzerlik gösterdiği söylenebilir. Anılan çalışmada, bölgede filmetkili turizmin gelişmesi ile ortaya çıkan olumlu ekonomik etkilerin yanı sıra, insan ilişkilerinde maddi çıkarcılık, ahlaki ve manevi değerlerin zarar görmesi gibi toplumsal açıdan olumsuz etkiler, bölge halkı tarafından aktarılan sorunlar arasında yer almıştır.

Çalışmanın, farklı eğitim seviyesi, yaş grupları ve gelir seviyelerine mensup yerel halkın, bölgede çekilen dizi ve filmlere ilişkin algılarını incelemesi nedeniyle, uygulamacılar açısından önem arz ettiği düşünülmektedir. Bu çalışmadan elde edilen bulguların, konuyla ilgili kişi ve kurumların planlamalarına yardımcı bir çalışma olarak değerlendirilmesi ve sonraki çalışmalara bir yön çizmesi, yazarların beklentileri arasındadır. İleriye yönelik yapılacak çalışmalar arasında, Türkiye'nin film ve dizi çekimlerinin yoğun olarak çekildiği bölgelerde, yerel halkın algı ve tutumlarını analiz etmeye yönelik daha kapsamlı çalışmalar, çekilen dizi ve filmlerin toplumsal, ekonomik ve çevresel etkilerini ele alan çalışmalar araştırmacılara önerilebilir. Bugüne kadar daha çok film ve dizilerin turistler üzerindeki etkilerini analiz etmeye yönelik çalışmaların yanında, yöre halkının bakış açısıyla ele alınan bu çalışmaların hem yerel halkın memnun olmasına hem de yerel kültürün ve yaşam tarzının dizi ve filmlerde daha gerçekçi anlatılmasına katkısı olacağı düşünülmektedir.

Katkı Belirtme: Anketlerin uygulanması ve çalışmaya yaptığı katkılardan dolayı Özgül ÇiÇEK'e teşekkür ederiz.

\section{KAYNAKÇA}

Akdu, U. ve Akın, M.H. (2016). Film Ve Dizilerin Destinasyon Tercihine Etkileri, Uluslararası Sosyal Araştırmalar Dergisi, 9(45): 1042-1052.

Atsız, O. ve Kızılırmak, İ. (2017). Mardin'in Doğal ve Kültürel Çekiciliklerinin Destinasyon Pazarlaması Kapsamında İncelenmesi, Mukaddime, 8(1): 25-41.

Aydın, A. (2008). İktisadi Açıdan Bölgesel Dengesizlik: Mardin İli Örneği, Elektronik Sosyal Bilimler Dergisi, 7(24): 304-312.

Aydın, S., Emiroğlu, K., Özel, O. ve Ünsal, S. (2000). Mardin Aşiret-Cemaat-Devlet. İstanbul: Tarih Vakfi.

Balli, F., Balli, H. Ö. and Cebeci, K. (2013). Impacts of Exported Turkish Soap Operas and VisaFree Entry on Inbound Tourism to Turkey. Tourism Management, 37: 186-192.

Beeton, S. (2008). From the Screen to the Field: The Influence of Film on Tourism and Recreation, Tourism Recreation Research, 30(1): 39-47.

Busby, G. and Klug, J. (2001). Movie-Induced Tourism: The Challenge of Measurement and Other Issues. Journal of Vacation Marketing, 7(4): 316-332.

Çakır, F. (2014). TV Dizilerinin Destinasyon İmajı Üzerine Etkisi, Adnan Menderes Üniversitesi, Sosyal Bilimler Enstitüsü Dergisi, 1(2): 80-89. 
Çakmak, V., Karadağ, Ş. ve Solmaz, B. (2011). Popüler Kültür Bağlamında Filmlerin ve Televizyon Dizilerinin Destinasyon İmajına Etkileri: “Yer Gök Aşk" Dizisi Üzerine Bir İnceleme, 1. Uluslararası Nevşehir Tarih ve Kültür Sempozyumu, s:105-118.

Dorsay, A. (1998). En Kolay İhraç Edilebilir Ürün Sinemadır (Söyleşi), TÜRSAB Dergisi, 17:36-37.

Egresi, I., Bayram, B. and Kara, F. (2012). Economic Impact of Religious Tourism in Mardin Turkey, Journal of Economics and Business Research, 28(2): 7-22.

Gunduz, E. and Erdem, R. (2013). Is There a Conflict Between Local Communities and Tourism? Mardin Sample., 53rd Congress of the European Regional Science Association: "Regional Integration: Europe, the Mediterranean and the World Economy", 27-31 August 2013, Palermo, Italya.

Günal, V. (2005). Mardin İlinde Kültürel Turizm Potansiyeli, Marmara Coğrafya Dergisi, 11:91-122.

Hudson, S. and Ritchie, J.R.B. (2006). Film Tourism and Destination Marketing: The Case of Captain Corelli's Mandolin. Journal of Vocational Marketing 12(3), 256-268.

Kaplanoğlu, E. (2014). Muhasebe Stajyerlerinin Meslek Mensuplarından ve Meslek Örgütlerinden Beklentileri: Manisa İli Araştırması, Atatürk Üniversitesi İktisadi ve İdari Bilimler Dergisi, 28(4): 265-284.

Karasu, A. (2013). Türkiye'de İzlenen Turizm Politikaları: Mardin Turizmine Yansımaları, Yayınlanmış Yüksek Lisans Tezi. Düzce: Düzce Üniversitesi Sosyal Bilimler Enstitüsü.

Kaygalak, S., Usta, Ö. ve Günlü, E. (2013). Mardin'de Turizm Gelişimi İle Otantik Olgusu Arasındaki İlişkinin Sosyolojik Açıdan Değerlendirilmesi, Anatolia: Turizm Araştırmaları Dergisi, 24(2): 237-249.

Kervankıran, İ. ve Aktürk, M. (2016). Türkiye'de Yazılı Medyanın Turizme Yaklaşımı: Sorun Çok, İlgi Yok, Journal of Recreation and Tourism Research, 3(2): 36-49.

Kim, H. and Richardson, S. L. (2003). Motion Picture Impacts on Destination Images, Annals of Tourism Research, 30(1): 216-237.

Mardin İl Kültür ve Turizm Müdürlügü. (2015). http://www.mardinkulturturizm.gov.tr/ (Erişim Tarihi: 25.06.2017).

Mardin Valiliği İl Çevre ve Orman Müdürlüğü. ( 2011). Mardin İli 2010 Yılı Çevre Durum Raporu. Mardin: Mardin İl Çevre ve Orman Müdürlüğ̈̈.

Nuroğlu, E. (2013). Dizi Turizmi: Orta Doğu ve Balkanlar'dan Gelen Turistlerin Türkiye'yi Ziyaret Kararında Türk Dizileri Ne Kadar Etkili? 5. Uluslararası İstanbul İktisatçılar Zirvesi, Küresel ve Bölgesel Değişim Sürecinde Yeni Türkiye'nin Ekonomik Vizyonu, İstanbul, 31 Ekim-1 Kasım 2013:. $1-13$.

Özdemir Güzel, S. ve Aktaş, G. (2016). Türk Televizyon Dizilerinin Destinasyon İmajina ve Seyahat Etme Eğilimine Etkisi: Atina Örneği, Anatolia: Turizm Araştırmaları Dergisi, 27(1): 111-124.

Piggott R., Morgan N. and Pritchard A. (2004). New Zealand and The Lord of the Rings: Levearing Public and Media Relations, in Destination Branding Creating the Unique Destination Proposition (2nd Ed.) Edt Morgan, N., Pritchard, A. and Pride Roger, Elsevier ButterworthHeinemann: Oxford.

Riley, R., Baker, D. and Van Doren, C.S. (1998). Movie Induced Tourism, Annals of Tourism Research, 25(4): 919-935. 
Russell, C. A. (1998). Toward A Framework of Product Placement: Theoretical Propositions, in Advances in Consumer Research Editor: Joseph W. Alba and J. Wesley Hutchinson, Provo, UT: Association for Consumer Research, pp:357-362.

Saltık, I.A., Coşar, Y. ve Kozak, M. (2010). Televizyon Dizilerinin Destinasyon Pazarlaması Açısından Olası Sonuçları, Anatolia: Turizm Araştırmaları Dergisi, 21(1): 41-50.

Soydan, E. ve Şarman, N. (2013). Mardin ve Şırnak İllerindeki Süryanilere Ait Dini Yapıların Kültür (ve İnanç) Turizmi Potansiyeli, International Journal of Social Science, 6(8): 589-607.

Şahbaz, R.P. ve Kılıçlar, A. (2009). Filmlerin ve Televizyon Dizilerinin Destinasyon İmajına Etkileri, İşletme Araştırmaları Dergisi, 1(1): 31-52.

Tatoğlu E., Erdal F., Özgür H. and Azaklı S. (2002). Resident Attitudes Toward Tourism Impacts: The Case of Kuşadası in Turkey, International Journal of Hospitality $\mathcal{E}$ Tourism Administration, 3(3): 79-100.

Tolüngüç, A. (1990). Türkiye'nin Dış Tanıtım ve Turizm Sorunları, Ankara: Ankara Üniversitesi Yayınları.

Tooke, N. and Baker, M. (1996). Seeing is Believing: The Effect of Film on Visitor Numbers to Screened Locations. Tourism Management, 17(2): 87-94.

Toprak, L. (2015). Mardin'de Halkın Turizm Alg1sı, Elektronik Sosyal Bilimler Dergisi, 14(54): 201218.

Tosun, C. (2001). Challenges of Sustainable Tourism Development in the Developing World: The Case of Turkey. Tourism Management, 22(3): 289-303.

Yanmaz, P. (2011). Turizm Tanıtımında Sinemanın Rolü, Gümüşhane Üniversitesi İletişim Fakültesi Elektronik Dergisi, e-gifder, 2: 112-139.

Yılmaz, H. ve Yolal, M. (2008). Film Turizmi: Destinasyonların Pazarlanmasında Filmlerin Rolü, Anadolu Üniversitesi Sosyal Bilimler Dergisi, 8(1): 175-192. 